\title{
Demutualization: Determinants and consequences of the mutual holding company choice
}

\author{
Kenneth A. Carow ${ }^{\mathrm{a},}$, Steven R. Cox ${ }^{\mathrm{b}}$, Dianne M. Roden ${ }^{\mathrm{b}}$ \\ ${ }^{a}$ Kelley School of Business, Indiana University, 801 West Michigan Street, Indianapolis, IN \\ 46202, USA \\ b Indiana University Kokomo, 2300 South Washington Street, Kokomo, IN 46904, USA
}

January 21, 2009

\begin{abstract}
We investigate the determinants and consequences of the mutual holding company (MHC) structure that allows mutual thrifts to issue stock to outside shareholders while maintaining the mutual form. Capital constrained firms with greater profit opportunities are more likely to choose a full demutualization; demonstrating that the MHC choice can be used to control for over- and under-investment costs. During periods of greater regulatory constraints, MHC firms have lower offer-day returns than full demutualizations. MHC firms are also less likely to be acquired as the MHC structure provides protection from the market for corporate control. Demonstrating a clear preference by minority shareholders for the elimination of the MHC structure, the announcement of a second-stage conversion generates a 12 percent return.

JEL classification: G21

Keywords: Mutual holding company; Thrifts; Event study; IPO; Conversion

* Corresponding author. Tel.: +1 317274 2783; fax: +1 3172743312.

E-mail addresses: kcarow@iupui.edu (K.A. Carow), scox@iuk.edu (S.R. Cox), droden@iuk.edu (D.M. Roden)
\end{abstract}

This paper was originally submitted to Professor Giorgio Szego on August 15, 2007 and was revised twice prior to submission through EES. 


\section{Introduction}

In the thrift industry, firms can be organized as a mutual, a stock company, or as a mutual holding company (MHC), a hybrid of the other two structures. Mutuals are nominally owned by their depositors but actual ownership rights are very limited. In a full demutualization, a mutual thrift is converted to a stock company as $100 \%$ of the firm is sold in the form of publicly traded shares to depositors and insiders who elect to participate. The new shareholders then own both their contributed capital and the equity that accumulated prior to the demutualization.

Some mutual thrifts establish a MHC as an alternative means to convert to a stock company. A MHC structure has two classes of shareholders. Minority shares are sold to participating depositors and insiders in an initial public offer and trade in the secondary market. The maximum ownership of these minority shares is $49.9 \%$. The majority position (a minimum of $50.1 \%$ of voting control) is jointly owned by the depositors, who are considered owners. Depositors retain a non-transferable right to purchase the majority shares if the corporation subsequently fully demutualizes in a second-stage offer. This study investigates the determinants and consequences of the choice to use a MHC structure compared to a full demutualization.

The MHC structure provides a variety of potential benefits. Thrift depositors may be more likely to approve this hybrid form because it retains a mutual element. As a result, thrift insiders may consider conversion to a MHC less controversial, faster, and less expensive than a full demutualization. In addition, management frequently posits that the MHC structure enables them to control the level of capital raised in the initial public offer. As summarized by the CEO of United Financial Group, "if it had sold 100\% of its stock, the company would have raised far more capital 'than we could profitably put to use'” (Kline, 2006). Finally, under the Gramm- 
Leach-Bliley Act, MHCs also obtain many of the benefits of a financial holding company, permitting MHCs to engage in a wide variety of financial services. ${ }^{1}$

Despite the benefits, the MHC structure introduces potential agency costs as insiders are insulated from market discipline. While the MHC structure permits acquisitions by the firm, the structure curtails acquisition of the MHC. While publicly held minority shares have voting rights, the majority shares are voted by the MHC depositors. The conflict is summarized in the offer prospectus of BCSB Bankcorp, Inc., the "MHC will be able to elect all members of the Board of Directors of the Company, and will be able to control the outcome of all matters presented to the stockholders of the Company for resolution by vote except for certain matters that must be approved by more than a majority of stockholders of the Company.” In addition, because the Office of Thrift Supervision (OTS) permits the waiver of dividends by majority shareholders (the MHC), minority shareholders may benefit from an enhanced dividend stream (Carow, Cox and Roden, 2004).

We find evidence consistent with tension between using the MHC structure to reduce over-investment concerns at the time of the IPO and increased managerial agency costs after the IPO. Our sample period covers 1991 - 2004 and includes 86 thrifts that converted using a MHC structure and 344 thrifts that chose full conversions. We find capital constrained firms with greater profit opportunities are more likely to choose a full demutualization. Conversely, wellcapitalized firms with fewer profit opportunities are more likely to choose the MHC structure; demonstrating that the MHC choice can be used to control for over- and under-investment costs. Firm behavior following the IPO is also consistent with the demutualization choice, including the

1 “This change will give MHCs parity with financial holding companies, which have the ability to create financial supermarkets - banking, brokerage and insurance - all offered under one holding company.” (Federal Register, July 12, 2000) 
consideration of investment opportunities. Relaxed MHC regulations increase the likelihood that a firm chooses the MHC structure.

MHCs may be a transitional structure. Of the 86 MHCs in the study, 34 completed a second-stage conversion to a $100 \%$ publicly traded stock company. The average time between a MHC first going public and the MHC converting to a full stock corporation is 3.9 years. The abnormal returns surrounding the announcement of the second-stage offer average 12 percent, demonstrating that minority shareholders react positively to the elimination of the MHC structure. In the second-stage conversion, depositors, as majority voters, are given nontransferable rights to purchase stock at an average discount of 9.9 percent. Minority shareholders are generally excluded from participation in the rights offer. The typical first-day gain for depositors subscribing to the offer is 9.5 percent, while the value of outstanding minority stock decreases by 1.7 percent.

Our contributions to the financial literature are three-fold. First, we document the life cycle of the MHC, showing that MHCs may be viewed as a transitional structure that culminates in conversion to a full stock corporation. Second, we provide evidence that the choice of full demutualization versus the MHC structure is partially explained by the investment opportunities and capital needs of the firm. Third, despite the potential benefits of reduced over-investment at the time of the IPO, minority shareholders subsequently demonstrate they value the benefits of full demutualization by responding positively when the MHC structure is dissolved.

The remainder of this paper is organized as follows. Section 2 provides background information on thrift demutualizations and changes in the regulatory environment. Our data are described in Section 3. Our empirical predictions are summarized in Section 4, results are presented in Section 5, and we state our conclusions in Section 6. 


\section{Background}

Mutual thrift insiders who intend to convert their organizations to stock form must choose either a full conversion or a MHC structure. Both methods raise capital, create common stock that improves access to future capital, assist in acquisitions, and can be used to offer stock incentives to management. Both methods also allow insiders and participating depositors the opportunity to realize significant initial returns when the accumulated value of a mutual is transferred to new shareholders. Barth, Brumbaugh and Kleidon (1994) report average initial returns from full conversions of 24\% for 1992 and 29\% for 1993. Carow, Cox, and Roden (2007, 2004) find a $20.8 \%$ average offer-day return from a sample of 347 mutual thrifts that utilized full demutualizations from 1991 to 2004 and a 19.9\% average offer-day return for 61 MHCs.

While conversions to a full stock company or a MHC create stock, raise capital, and enrich participants in the IPO, there are three important differences between the two alternatives. First, a MHC raises less cash because it can only sell up to 49.9 percent of the company. As a result, having the choice of a full demutualization or a MHC structure may allow thrift insiders to better match the size of the IPO to the firm’s investment opportunities and capital needs.

Second, from the standpoint of thrift insiders, the MHC conversion retains the mutual nature of the thrift and allows creation of a stock company that is not subject to market discipline. $^{2}$ The MHC conversion essentially creates two classes of common stock. One class, referred to as the majority shares, is jointly held by the MHC depositors and the second class is

\footnotetext{
2 "A majority of the voting stock of the Company will be owned by the MHC, which is a mutual institution that will be controlled by the existing Board of Directors of the Bank. While this structure will permit management to focus on long-term business strategy for growth and capital redeployment without undue pressure from stockholders, it will also serve to perpetuate the existing management and directors of the Bank”(excerpt from the prospectus of BCSB Bankcorp Inc).
} 
publicly held by the minority stockholders. ${ }^{3}$ The majority MHC shares may be viewed as a nontransferable right to purchase shares in a future stock offer if the company fully demutualizes. Minority shares are traditional shares with inferior voting rights. Louis (2004) and Hughes et al. (2003) show that bank insiders value takeover protection, even though it reduces the market value of the bank. Bebchuk, Kraakman, and Triantis (1998) model how a dual-class structure can substantially increase agency costs. Lease, McConnell, and Mikkelson (1983), Megginson (1990), Zingales (1995), and Cox and Roden (2002) show that shares with inferior voting rights trade at a discount compared to shares with superior voting rights. Similarly, Harris and Raviv (1988), Smart and Zutter (2003), Claessens, Djankov, Fan, and Lang (2002), and Cronquist and Nilsson (2003) show that separation of cash-flow from voting rights lowers market values.

Third, the MHC structure provides thrift insiders with a two-stage exit strategy that allows control of the thrift until they choose to convert to a full-stock company. In the secondstage conversion, shares held by the public shareholders are exchanged for shares of a "new" holding company at a specified exchange ratio that is calculated to retain their percentage ownership. This second-stage offer is similar to a rights offer, but the economic implications differ. In a traditional rights offer, existing stockholders receive rights to purchase the stock at a discounted price and the rights are saleable. In a MHC second-stage conversion, non-transferable rights to purchase additional shares are first given to the existing thrift depositors. Similar to the first-stage conversion, depositors who do not purchase stock at the offer price forfeit the economic value of their rights. In this way, the MHC dissolves the former structure and converts to a full stock corporation.

${ }^{3}$ The majority shares may receive dividends in the form of additional shares. Current regulations allow MHCs to pay dividends to minority shareholders while omitting dividends to majority shareholders. Carow, Cox, and Roden (2004) show that MHCs transfer wealth to minority shareholders through disparate dividend policy. 
Congress first authorized MHCs in 1987, but prior to 1992, only one thrift adopted the MHC structure. The OTS first published proposed regulations for MHCs in 1991 and the regulations were finalized in 1993. In 1995, the OTS and FDIC prohibited MHCs from waiving MHC dividends for the benefit of minority shareholders (grandfathering existing MHCs). However, in 2000 policy changes "were deliberately made to make the MHC structure more attractive as a long-term alternative to full conversion," including the reversal of the 1995 dividend decision. ${ }^{4}$

In 1997 the Office of Thrift Supervision (OTS) authorized credit unions to convert to a federal mutual thrift charter in one step. ${ }^{5}$ In 1998, the OTS authorized a three-tier MHC, allowing MHCs to establish a subsidiary that could sell stock and later buy it back without adverse tax consequences. ${ }^{6}$ Under the Gramm-Leach-Bliley Act of 1999, MHCs were allowed to engage in similar activities as financial holding companies; including banking, brokerage and insurance. In 2002 regulations relaxed MHC limitations on the amount of compensation managers may receive through management recognition plans (MRPs) and stock option plans.

\section{Data}

Our sample includes first and second-stage conversions of mutual thrifts from 1991 to 2004. Our sample of 86 MHCs and 344 fully demutualized thrifts is obtained from SNL DataSource and SNL Securities Monthly Market Report. SNL DataSource provides details on offer proceeds, offer price, shares outstanding, insider participation, ROA, core capital ratio, asset growth, loans-to-assets ratio, and the thrift industry average price-to-book ratio.

\footnotetext{
${ }^{4}$ Federal Register, July 12, 2000

${ }^{5}$ Press Release OTS, August 26, 1997

${ }^{6}$ Press Release OTS, June 5, 1997 and Press Release OTS, March 9, 1998
} 
Table 1 provides the frequency of each type of conversion by year. MHCs grew from 0 percent in 1991, to 40 percent in 2002, and to 85 percent in 2004. Of the 86 MHCs that initiated IPOs over the sample period, 34 have subsequently completed a second-stage conversion.

Table 2 provides summary information for our sample and compares characteristics of thrifts that use a MHC structure with thrifts that undergo a full conversion. ASSETS is calculated as the log of the firm's total assets in thousands in the year prior to the demutualization. PROC is defined as the log of proceeds from the offer in thousands. GROWTH is the percent increase in assets in the year prior to the conversion. $R O A$ is the percent return on assets in the year prior to the offer. CORE is tier 1 capital divided by risk-adjusted assets as a percentage in the year prior to the offer. LOANS is loans divided by total assets as a percentage in the year prior to the offer. $I N D \_P / B$ is the thrift industry average price-to-book ratio in the year of the demutualization. INSIDE is the percent of the shares purchased by officers and directors. $\triangle P R I C E$ is the percent price change on the first day of the IPO.

Thrifts that choose the MHC form are significantly larger, faster growing, and more profitable. They convert during times of higher industry price-to-book ratios and raise significantly less cash. Without controlling for other factors, the average offer-day returns are not significantly different.

\section{Empirical Predictions}

In this section, we provide a brief overview of our empirical predictions relating to the determinants and consequences of the choice of the MHC structure. This discussion provides a framework for the results section where we summarize the related literature as we present the empirical findings.

\subsection{Prediction 1}


We hypothesize that firms with greater investment opportunities and less capital are more likely to choose a full demutualization since it raises more capital than the MHC structure. Firms with fewer investment opportunities and greater capital are more likely to choose the MHC structure since it raises less capital. Our primary test of this hypothesis is based on a three-way interaction between the thrift's level of capital, profitability, and the loans-to-assets ratio.

Carow, Cox, and Roden (2007) show that larger thrifts, better performing thrifts, and thrifts that convert under favorable industry conditions are capable of raising more capital. More capital increases the potential for over-investment. As suggested by some MHC managers, the choice of the MHC structure may be motivated by the decision to raise less capital. However, for thrifts with significant growth opportunities, the MHC structure may raise too little capital and result in under-investment. Hence, in addition to evaluating the firm characteristics that lead to the choice of using an MHC, we also evaluate firm investment performance and capital levels subsequent to the IPO.

\subsection{Prediction 2}

We posit that a more favorable regulatory environment increases the popularity of the MHC structure and offer-day returns for MHCs. Throughout our sample period regulatory incentives changed for MHCs. The most restrictive period began in February of 1995 when the OTS and FDIC prohibited MHCs from waiving dividends. The most favorable period was subsequent to the removal of this policy in July 2000.

\subsection{Prediction 3}

The choice to convert using a MHC may create agency problems that can be observed throughout the structure's life cycle. We hypothesize that, at the time of the conversion, thrifts that choose a structure inconsistent with its capital and investment opportunities will realize 
lower initial returns. After the conversion, a MHC may experience greater managerial agency costs, compared to thrifts that chose full demutualizations, as thrift insiders remain insulated from market discipline. Based on the conclusions of Masulis (1987, p 30), "that organizational change occurs when economic efficiencies are to be gained", we hypothesize that the announcement of the conversion of a MHC to a full stock-based company will be treated positively by investors.

\section{Results}

\subsection{Full demutualization versus $M H C$}

Our first and second empirical predictions relate to the impact of thrift characteristics and market conditions on the MHC choice. Prior studies indicate that IPO determinants include capital, growth, industry growth, and assets (Davis, 2001; Maksimovic and Unal, 1993; Pagano, Panetta, and Zingales, 1998). Carow, Cox, and Roden (2007) show assets, industry price-to-book ratios, capital, and profitability are primary determinants of the level of proceeds in full demutualizations. In order to control for the potential influence of industry conditions in our empirical tests, we adjust our previously defined variables of growth, capital, ROA, and loans-toassets by subtracting the median for publicly traded thrifts at the time of the observation $\left(G R O W T H^{\wedge}, R O A \wedge, C O R E^{\wedge} \text {, and } L O A N S^{\wedge}\right)^{7}$

We also include an indicator variable to identify firms with both profitable growth opportunities and capital constraints. Firms that are constrained from taking on greater profit opportunities more fully utilize their capital and take on more loans relative to their asset base. We define (CONSTRAIN) equal to one for firms with ROA greater than industry median, loansto-assets greater than industry median, and capital less than industry median; 0 otherwise.

\footnotetext{
${ }^{7}$ Similar results are obtained when we use the firm ratios without adjusting for industry.
} 
Similarly, to identify non-constrained firms, we define (NON-CONSTRAIN) equal to one for firms with low ROA, low loans-to-assets, and high capital.

Table 3 presents the results from a logistic regression of the choice to use a MHC structure versus a full demutualization. The results are consistent with management's statement that thrift insiders choose their structure to match the expected levels of profitable investment opportunities. We find constrained firms with profitable growth opportunities are more likely to raise larger amounts of capital through a full demutualization. Non-constrained firms with less profitable growth opportunities are more likely to choose the MHC structure to curtail the potential of over-investment. Consistent with firm size and industry performance increasing the potential level of capital raised in the IPO, we find larger firms and firms issuing stock during periods of better industry performance are more likely to choose the MHC structure.

Consistent with our second prediction, the regulatory environment has a significant impact on the decision to use the MHC structure. Table 3 shows firms that demutualize in years with a more favorable regulatory environment (prior to 1995 and following 2000) are more likely to use the MHC structure. Thrifts are less likely to use a MHC structure during the period between 1995 and 2000 when new MHCs were not allowed to waive dividends.

Although, the results presented in Table 3 provide evidence that constrained firms choose full demutualizations while non-constrained firms choose the MHC structure, the logit model does not consider the level and use of capital subsequent to the IPO. If the MHC structure, which raises less capital at the IPO, creates agency costs due to under-exploited investment opportunities, then affected firms with capital constraints subsequent to the IPO will choose to invest in projects with the highest returns, providing greater increases in net interest margin 
(NIM) and ROA. In Table 4, we evaluate the level and changes in these characteristics relative to industry three years after the IPO.

Management could have raised more capital had they issued $100 \%$ of the stock to the public through a full demutualization versus issuing less than $50 \%$ of the stock through the MHC structure. This choice of slower growth is evident in the slower asset growth for MHCs following the IPO.

We evaluate whether the future investment opportunities taken by the firm are consistent with the claim of MHC managers, that a full demutualization would provide too much capital to manage efficiently. If, on the other hand, MHCs have substantial agency costs due to underexploited investment opportunities, one would expect management to take advantage of as many investment opportunities as their capital permits. This would result in greater utilization of capital, higher levels of loans-to-assets, faster growth in ROA (reflecting the value of selecting only superior growth opportunities), and increasing net interest margins (reflecting the ability of MHCs to "cherry-pick" the best investment opportunities relative to fully demutualized thrifts).

First, we address the utilization of capital. If MHCs are constrained due to smaller capital offers, they should subsequently exhibit lower capital ratios and should return to their pre-IPO capital ratio faster than full demutualizations. Instead, we find that MHCs maintain higher levels of Tier 1 Capital and MHC capital ratios approach their pre-IPO capital ratio at a slower rate than fully demutualized firms.

Second, we look for evidence of missed growth opportunities. Three years following the IPO, neither the level nor the growth in ROA and NIM, reflect firms "cherry-picking" underutilized growth opportunities. If MHCs had significantly greater investment opportunities relative to the size of their offer, they would be more likely to increase the amount of loans 
relative to their asset base. We find MHCs have significantly lower loans-to-assets ratios. Therefore, neither growth, nor profitability measures support the hypothesis of MHCs underinvesting relative to full demutualizations.

Third, we address measures of risk on the firm's investments. Firms that have too much capital are more likely to over-invest in new projects. Firms that over-invest are expected to invest in poorer performing assets (higher levels of nonperforming loans and higher levels of reserves). ${ }^{8}$ The levels of nonperforming assets and reserves are similar for both MHCs and full demutualizations; however, thrifts that fully demutualize significantly increase their levels of nonperforming assets and reserves relative to the levels prior to the IPO. These findings are consistent with thrifts that fully demutualize investing in potentially riskier assets to utilize their capital.

The results of Table 4 suggest that managers behave in a manner consistent with MHCs having fewer growth opportunities relative to the potential amount of capital raised in the IPO. MHCs grow slower, maintain higher levels of capital, maintain lower loans-to-assets ratios, are less likely to return to their pre-IPO capital levels, and do not experience significantly higher performance. These findings are supportive of the proposition that firms with fewer investment opportunities relative to their potential level of capital are more likely to choose the MHC form.

\subsection{IPO returns}

Table 5 provides the results of an ordinary least squares regression using offer-day returns as the dependent variable. The offer-day return ( $\triangle P R I C E)$ at the IPO is higher for larger, more profitable firms, with greater inside participation, and higher industry price-to-book ratios.

\footnotetext{
${ }^{8}$ This is based on the assumption that the level of capital raised is exogenous to the MHC choice. Carow, Cox, and Roden 2007, show that in full demutualizations managers have discretion in adjusting the size of the offer. This paper shows that managers can also affect offer size through the decision to choose a full versus partial demutualization.
} 
The coefficients for the control variables are consistent with the findings of Carow, Cox, and Roden (2007) and the model presented in Masulis (1987) and Maksimovic and Unal (1993).

Our second prediction posits that MHCs in a more restrictive regulatory period will have lower returns. Controlling for the determinants of initial returns, we find that MHCs going public during the regulatory period requiring dividend waivers have significantly lower initial returns (6.90\%) than full demutualizations. Returns prior to 1995 and subsequent to 2000 are not significantly different from returns for full demutualizations.

Our third prediction suggests that thrifts that choose a structure inconsistent with its capital and investment opportunities will realize lower initial returns. In column 2 of Table 5, we include four additional variables. We interact each of the constraint variables from the logit model with the decision to choose a full or a partial (MHC) demutualization. As shown in the logit model, CONSTRAIN (NON-CONSTRAIN) firms were more likely to choose a full demutualization (MHC structure) to raise greater (less) capital for their more (less) profitable growth opportunities. We expect firms that choose the structure that matches their firm characteristics will have higher returns. For the variable MHC_CONSTRAIN, the coefficient indicates that constrained firms that chose the MHC structure had returns 19.6 percent below the returns of other firms. This reflects the risk of under-investment when firms with greater capital needs inconsistently choose the MHC structure. While not significant, we find the expected negative coefficient for NONMHC_NON-CONSTRAIN. This is consistent with increased overinvestment risk when firms that do not need capital choose a full demutualization. In contrast, firms that match their capital needs with their structural choice, unconstrained firms that choose the MHC structure and constrained firms that choose a full demutualization, do not suffer lower IPO returns. 
Similar results are found in models 3 and 4 , when we define the dependent variable as the $\log$ of the dollar gain from the IPO. ${ }^{9}$ The MHC_CONSTRAIN coefficient indicates that firms that were constrained but chose the MHC structure had smaller dollar gains than other firms. While not significant, we find NONMHC_NONCONSTRAIN shows lower dollar gains. ${ }^{10}$

\subsection{Probability of becoming a target or an acquirer}

Zingales (1995) and Mello and Parsons (1998) view the IPO as the first stage in establishing a price for the subsequent sale of the firm. Rosen, Smart, and Zutter (2005) show that banks undergoing an IPO are significantly more likely to become acquisition targets than a matched sample of private banks. However, Field and Karpoff (2003) show that IPO firms with dual-class stock or anti-takeover provisions are less likely to be acquired in the five years following the offer. Regulations prevent both full demutualizations and MHCs from becoming an acquisition target for three years after the IPO. MHCs have the additional protection of three more years after a second-stage conversion.

As shown in Table 6, over our sample period 39 percent of full demutualizations were acquired while only 9 percent of firms that chose the MHC structure were acquired. Of the 8 MHCs that were acquired, only one did not first complete a second-stage conversion. The number of years from the time of the IPO to the time of acquisition is not significantly different

\footnotetext{
${ }^{9}$ Agency costs are reflected in the gains from the offer. As in Carow, Cox and Roden (2007), returns from the initial offer measure the "prior market value of the thrift plus the present value of the growth opportunities" as a percent of proceeds raised, ( $\left.\mathrm{V}_{0}+\mathrm{PVGO}\right) /$ PROCEEDS. Carow, Cox, and Roden also show that the size of the offer proceeds may be influenced by management to affect returns, suggesting that division by proceeds may bias our results. To demonstrate the robustness of our results, in models 3 and 4 we use the dollar amount of the gain from the offer, an estimate of $\left(\mathrm{V}_{0}+\mathrm{PVGO}\right)$.

${ }^{10}$ Note the coefficient for inside holdings is insignificant in the model explaining the dollar gain, but significantly positive in the offer-day return where the dollar gain is scaled by proceeds. This result is consistent with Carow, Cox, and Roden (2007), where they posit that management influences the size of the offer to enhance the returns to IPO investors.
} 
for MHCs compared to full demutualizations. Consistent with our third prediction, MHCs are significantly less likely to become targets than full demutualizations, confirming that the MHC structure offers protection from the corporate control market.

Consistent with an influx of additional capital, Rosen, Smart, and Zutter (2005) show that banks that convert to public ownership are more likely to make acquisitions. The capital raised in the IPO can be used to finance cash acquisitions and the firm's publicly traded stock provides a better medium for stock-financed acquisitions. Since the offer proceeds are smaller and the stock of the MHC is less appealing as a medium of exchange due to its restricted control rights, we expect MHCs to make fewer acquisitions relative to fully demutualized firms.

We find that the percent of MHCs making acquisitions is similar to the percent of fully demutualizing firms making acquisitions; however, the number of years before making an acquisition is significantly longer for MHCs. Since MHCs raise proportionately less capital and have a more complex ownership structure, they typically wait to complete a second-stage conversion to raise the necessary capital for an acquisition. Of the 16 MHCs that made acquisitions, only 4 made an acquisition prior to a second-stage conversion.

\subsection{Post IPO performance}

Using a sample of banks and thrifts that go public between 1983 and 1991, Houge and Loughran (1999) examine post-IPO performance. They find that IPOs substantially underperform the industry in the years following the IPO. Table 7 summarizes measures of performance after the demutualization (returns exclude offer-day initial returns). For comparison, we provide unadjusted returns and returns adjusted for the average thrift industry. ${ }^{11}$ One-year

${ }^{11}$ To calculate adjusted returns we subtract the cumulative return from a portfolio of thrifts trading on CRSP during the same period from the cumulative return for the individual company 
stock returns for non-MHCs average 31.7 percent (-7.9 percent net of thrift industry returns) compared to 20.6 percent for MHCs (-10.0 percent net of thrift industry). However, after three years, cumulative stock returns for MHCs are significantly greater than the three-year stock returns of full demutualizations; non-MHCs average 88.0 percent (-58.2 percent net of thrift industry) and MHCs average 123.7 percent (-19.1 percent net of thrift industry). In summary, when we control for industry performance, MHCs significantly outperform full conversions in the three years following the IPO. ${ }^{12}$ However, both forms of thrift IPOs underperform relative to the thrift industry.

\subsection{Second-stage conversion choice}

For many MHCs the ownership structure appears to be a transitional form. Of the 86 firms that chose to use the MHC structure, 34 chose to complete a second-stage conversion. For these 34 companies, the average time between the IPO and the completion of the second-stage conversion is 3.9 years. For MHCs that do not convert, the average time from IPO to the end of our sample period is only 3.7 years, indicating that the percent of MHCs that will ultimately conduct a second-stage conversion may be significantly higher. In results not reported in tables, we find that MHCs are more likely to choose a second-stage conversion when they are larger and have lower capital.

\subsection{Second-stage conversion returns}

A second-stage offer combines an equity offer with the elimination of a dual-class voting structure. Table 8 reports the results of the abnormal returns surrounding the initial

stock. Similar adjusted returns are found when we include both banks and thrifts in the industry portfolio.

12 In regression results not reported in tables, we show that three-year cumulative returns are still significantly higher for MHCs after we control for whether the firm makes an acquisition or becomes a target. 
announcement of the second-stage conversion and the offer date. ${ }^{13}$ Consistent with prediction 3 , the mean two-day abnormal return at the time of the announcement of the second-stage conversion is 12.3 percent. Note that this reaction reflects the expectations of the minority shareholders who do not profit at the time of the second-stage offer. Thus, the positive response reflects a possible combination of the long-term preference of minority shareholders' for the elimination of the MHC structure and the present value of growth opportunities resulting from the expected inflow of capital.

Previous literature shows negative average abnormal returns of approximately 3 percent over a two-day announcement period for firm commitment equity offers (Asquith and Mullins, 1986; Masulis and Korwar, 1986; Eckbo and Masulis, 1992) and negative average abnormal returns of approximately 1.5 percent for rights offers (White and Lusztig, 1980; Eckbo and Masulis, 1992). These negative announcement returns exist in spite of potential growth opportunities resulting from the inflow of capital. In contrast, previous research finds strong positive reactions to transactions that remove a dual-class structure (Smart and Zutter, 2003, Dittmann and Ulbricht. 2007). Therefore, we conclude that the significantly positive announcement returns for second-stage conversions is also due to the elimination of the MHC dual-class structure.

At the time of the second-stage offer, there are two groups of potential participants. Nontransferable rights to purchase the shares at the offer price are issued to depositors of the MHC, also referred to in the prospectus as majority shareholders due to their $50.1 \%$ voting interest. As depositors in the MHC, insiders also participate in the offer. Minority shareholders only obtain a

\footnotetext{
${ }^{13}$ Four MHCs did not trade on the NYSE, AMEX, or Nasdaq stock exchanges at the time of the second-stage conversion, resulting in a final sample of 30 companies for estimating abnormal returns.
} 
right to purchase at the offer price if a significant portion of depositors forfeit their rights, which is rarely the case. Because the stock trades publicly prior to the second-stage offer, a stock price exists to compare to the offer price. Adjusting for the conversion ratio, we calculate the offer price discount [(prior price/conversion ratio - offer price) / (prior price/conversion ratio)], as in Bohren, Eckbo, and Michalsen (1997).

For our sample of MHC second-stage offers, the average discount is 9.9 percent with a standard deviation of 8.0 percent and a range of -0.1 to 30.3 percent. This compares with Loderer, Sheehan, and Kadlec (1991), Eckbo and Masulis (1992), Safieddine and Wilhelm (1996), and Mola and Loughran (2004), who report average offer price discounts ranging from 0.3 to 3.0 percent for seasoned equity offers. For rights offers, Eckbo and Masulis (1992) report an average discount from the prior day's closing price of 8.3 percent for industrials and 12.7 percent for utility issuers.

The level of the discount is expected to influence the company's stock price. ${ }^{14}$ To measure this effect, we calculate the abnormal returns to subscribers and non-subscribers

${ }^{14}$ Assuming no additional benefits from growth opportunities or from a reduction in agency costs, we illustrate the returns from a second-stage offer below. Assume that the mutual thrift carried \$2 of pre-existing value and that minority shareholders jointly paid \$10 for a single share in the first-stage offer. The minority shareholders now own a company worth $\$ 12$, and the share should trade at this value assuming no expectation of a discounted second-stage offer. Assume in a second-stage offer that depositors are jointly offered one share at a discounted price of approximately $\$ 10.80$ (based on our findings of a $9.9 \%$ average discount from market value). The firm is now worth $\$ 22.80$ (prior value assumed unchanged at $\$ 12$ plus the additional $\$ 10.80$ in new capital). The shares of the fully demutualized firm should be priced at $\$ 22.80 / 2$ or $\$ 11.40$ /share. This shows that the initial minority shareholders ultimately captured the bulk of the pre-existing value; $\$ 1.40$ for the initial shareholders vs. $\$ .60$ for the new shareholders. Depositors who participate in the second-stage offer receive a 5\% (\$0.60/\$12.00) discount from the company's market value prior to the second-stage offer and a 5.55\% (\$0.60/\$10.80) expected gain on the offer date. Note that the greater the discount, the more the prior value is redistributed from the minority shareholder to the depositors participating in the second-stage offer. When we allow for the expectation of a discounted second-stage offer, the stock price will increase by less than $\$ 2$ on the first-stage IPO date, due to the potential that a portion of the $\$ 2$ 
surrounding the second-stage offer date. The abnormal return to subscribers is calculated as the percent change in market price relative to the offer price with adjustments based on the market model. This return is from the perspective of a new investor, similar to the measurement used by Safieddine and Wilhelm (1996). The abnormal return to non-subscribers is calculated as the change in price from the close of the previous day with adjustments based on the market model. This return is from the perspective of existing minority shareholders who do not participate in the second-stage offer.

Table 8 part B shows the average one-day cumulative abnormal return to subscribers is 9.5\%. This demonstrates the potential for large gains to subscribers. Table 8 part $\mathrm{C}$ shows the average one-day cumulative abnormal return to existing shareholders who did not participate in the second-stage offer is $-1.7 \%$ on the offer date. ${ }^{15}$ This negative return is consistent with the negative offer-day returns on rights offers as reported by Eckbo and Masulis (1992). The negative return to existing stockholders along with the positive return to new subscribers implies a transfer of wealth from minority shareholders to new subscribers. New subscribers can purchase the shares at an average $9.9 \%$ discount. This discount reflects a lower price that is not available to current (minority) shareholders who are not depositors, resulting in a reduced value per share as the firm does not fully utilize its opportunity to raise additional capital at the current stock price. ${ }^{16}$

prior value will be reallocated to second-stage participants. Thus, the initial increase in value would be $\$ 2$ less the expected present value of the $\$ 0.60$.

${ }^{15}$ In studies of non-MHC stock offers, Safieddine and Wilhelm (1996) report the average offerto-close return is 0.52 percent, which lies between the returns of 0.12 percent observed by Loderer et al. (1991) and 0.82 reported in Smith (1977). Eckbo and Masulis (1992) report offer day returns of -0.21 percent for firm commitments, -1.10 percent for standby rights, and -1.33 percent for uninsured rights.

${ }^{16}$ In first-stage conversions, insiders who participate in the offer have clear incentive to set large discounts. However, in second-stage conversions insiders must balance potential losses in the 
The above results demonstrate that minority shareholders benefit from the removal of the MHC as do the depositors and insiders who participate in the second-stage offer. Shareholders that owned stock in the MHC prior to the second-stage offer gain $12.3 \%$ at the announcement, while only losing $1.7 \%$ of value on the offer date, for a net $10.6 \%$ gain from eliminating the MHC structure. Depositors who participate gain approximately 9.5\% on the first day of the offer. Similarly, Masulis (1987, p 30) concludes that "the major finding of this study is that, on average, all the major claimants in the MS\&Ls choosing to convert to stock charter gain from this action." and that the evidence "supports the agency theory prediction of Alchian (1950) and Jensen and Meckling (1976); namely, that organizational change occurs when economic efficiencies are to be gained.”

\section{Conclusions}

We provide a comprehensive analysis of the determinants and consequences of the MHC structure as an alternative to full demutualization. The MHC structure provides a flexible alternative to full demutualizations, allowing the thrift to maintain its mutual structure while accessing capital markets. Thrift insiders are able to retain protection from takeovers while outside minority shareholders are subjected to the agency costs of an insulated management.

Our results indicate that the MHC choice can be used to control for over- and underinvestment costs. Thrifts with less profitable investment opportunities and more capital are more likely to choose the MHC structure while thrifts with more profitable investment opportunities and less capital are more likely to choose a full demutualization. Firms that match their capital

value of their pre-existing stock holdings with the potential gains from inside participation in a heavily discounted second offer. Inside participation averages $0.9 \%$ (with a range of 0 to $3.3 \%$ ) of outstanding shares on the day of the second-stage conversion. In regressions not reported, we do not find evidence that pre-existing holdings and/or inside participation are correlated with the discount or the abnormal returns to subscribers. 
needs with their choice of full or partial (MHC) demutualization have higher offer-period returns. Returns are also higher during more favorable regulatory periods.

When we consider the level and use of capital subsequent to the IPO, our results are consistent with MHCs having fewer growth opportunities relative to the amount of capital raised in the IPO. MHCs grow slower, maintain higher levels of capital, maintain lower loans-to-assets ratios, are less likely to return to their pre-IPO capital levels, and do not experience significantly higher performance. These findings suggest that firms with fewer investment opportunities relative to their potential level of capital are more likely to choose the MHC form.

After formation, MHC insiders continued to be sheltered from the corporate control market, reducing the likelihood of being acquired. Over our sample period, nearly 39 percent of full demutualizations were acquired compared to only 9 percent of firms that chose the MHC structure. Of the 8 MHCs that were acquired, only one did not first complete a second-stage conversion. The stock price reaction to the announcement that a MHC intends to fully convert to a stock company demonstrates the preference of minority shareholders to remove the MHC structure. We find a positive stock price reaction (12.3 percent) to the announcement of a second-stage offer. Although the MHC structure seems to offer reduced risk of over-investment at the time of the IPO, after the IPO minority shareholders subsequently demonstrate they value enhanced growth opportunities and benefits of corporate control by responding positively when the MHC structure is dissolved. We conclude that this positive shareholder reaction reflects the elimination of the MHC dual-class structure that restricts growth and insulates MHC insiders from market discipline. 


\section{References}

Alchian, A., 1950. Uncertainty, evolution and economic theory. Journal of Political Economy 58, 211-221.

Asquith, P., Mullins, D., 1986. Equity issues and offering dilution. Journal of Financial Economics 15, 61-89.

Barth, J., Brumbaugh, D., Kleidon, A., 1994. Windfall gains in mutual-to-stock conversions of thrift institutions. Challenge (July/August), 43-49.

Bebchuk, L., Kraakman, R., Traiantis, G., 1998. Stock pyramids, cross-ownership, and dual class equity: The creation and agency costs of separating control from cash flow rights. Working paper, Harvard Law School.

Bohren, O., Eckbo, B.E., Michalsen, D., 1997. Why underwrite rights offerings? Some new evidence. Journal of Financial Economics 46, 223-261.

Carow, K., Cox, S., Roden, D., 2004. Mutual holding companies: Evidence of conflicts of interest through disparate dividends. Journal of Banking and Finance 28, 277-298.

Carow, K., Cox, S., Roden, D., 2007. The role of insider influence in mutual-to-stock conversions. Journal of Money, Credit, and Banking 39, 1285-1304.

Claessens, S., Djankov, S., Fan, J., Lang, L., 2002. Disentangling the incentive and entrenchment effects of large shareholders. Journal of Finance 57, 2741-2772.

Cox, S., Roden, D., 2002. The source of value of voting rights and related dividend promises. Journal of Corporate Finance 8, 337-351.

Cronqvist, H., Nilsson, M., 2003. Agency costs of controlling minority shareholders. Journal of Financial and Quantitative Analysis 38, 695-719.

Davis, K., 2001. Credit union governance and survival of the cooperative form. Journal of Financial Services Research 19, 197-210.

Dittmann, I., Ulbricht, N., 2008. Timing and wealth effects of german dual class stock unifications. European Financial Management 14, 163-196.

Eckbo, E., Masulis, R., 1992. Adverse selection and the rights offer paradox. Journal of Financial Economics 32, 293-332.

Field, L., Karpoff, J., 2003. Takeover defenses of IPO firms. Journal of Finance 57, 1857-1891.

Grossman, S., Hart, O., 1988. One-share-one-vote and the market for corporate control. Journal of Financial Economics 20, 175-202. 
Harris, M., Raviv, A., 1988. Corporate governance: Voting rights and majority rules. Journal of Financial Economics 20, 203-235.

Houge, T., Loughran, T., 1999. Growth fixation and the performance of bank initial public offerings 1983-1991. Journal of Banking and Finance 23, 1277-1301.

Hughes, J., Lang, W., Mester, L., Moon, C., Pagano, M., 2003. Do bankers sacrifice value to build empires? Managerial incentives, industry consolidation, and financial performance. Journal of Banking and Finance 27, 417-447.

Jensen, M., Meckling, W., 1976. Theory of the firm: Managerial behavior, agency costs, and ownership structure. Journal of Financial Economics 4, 305-360.

Kline, A., 2006. Why mutual holding company conversions are cooling off. American Banker (January), 171.

Lease, R., McConnell, J., Mikkelson, W., 1983. The market value of control in publicly-traded corporations. Journal of Financial Economics 11, 439-471.

Loderer, C., Sheehan, D., Kadlec, G., 1991. The pricing of equity offerings. Journal of Financial Economics 29, 35-57.

Louis, H., 2004. The cost of using bank mergers as defensive mechanisms against takeover threats. The Journal of Business 77, 295-310.

Luse, E., Gorman, J., 2005. Conversions - A review of 2004 and the outlook for 2005. SNL Interactive (March), 2005.

Maksimovic, V., Unal, H., 1993. Issue size choice and 'underpricing' in thrift mutual-to-stock conversions. Journal of Finance 48, 1659-1692.

Masulis, R., 1987. "Changes in ownership structure: Conversions of mutual savings and loans to stock charter. Journal of Financial Economics 18, 29-59.

Masulis, R., Korwar, A., 1986. Seasoned equity offerings: An empirical investigation. Journal of Financial Economics 15, 91-118.

Megginson, W., 1990. Restricted voting stock, acquisition premiums, and the market value of corporate control. The Financial Review 25, 175-198.

Mello, A., Parsons. J., 1998. Going public and the ownership structure of the firm. Journal of Financial Economics 49, 79-109.

Mola, S., Loughran, T., 2004. Discounting and clustering in seasoned equity offering prices. Journal of Financial and Quantitative Analysis 39, 1-23. 
Pagano, M., Panetta, F., Zingales, L., 1998. Why do companies go public? An empirical analysis. Journal of Finance 53, 27-64.

Rosen, R., Smart, S., Zutter, C., 2005. Why do firms go public? Evidence from the banking industry. Working paper, Federal Reserve Bank of Chicago.

Safieddine, A., Wilhelm, W., 1996. An empirical investigation of short-selling activity prior to seasoned equity offerings. Journal of Finance 51, 729-749.

Smart, S., Zutter, C., 2003. Control as a motivation for underpricing: A comparison of dual and single class IPOs. Journal of Financial Economics 69, 85-110.

Smith, C., 1977. Alternative methods for raising capital: Rights versus underwritten offerings. Journal of Financial Economics 5, 273-307.

White, R., Lusztig, P., 1980. The price effects of rights offerings. Journal of Financial and Quantitative Analysis 15, 25-44.

Zingales, L., 1995. What determines the value of corporate votes? The Quarterly Journal of Economics 110, 1047-1073. 
Table 1

Frequency of sample conversions by year

\begin{tabular}{cccccc}
\hline Year & Non-MHCs & MHCs & Total & $\begin{array}{c}\text { MHC as } \\
\text { Percent of Total }\end{array}$ & $\begin{array}{c}\text { MHC Second-Stage } \\
\text { Conversions }\end{array}$ \\
\hline & 3 & 0 & 3 & 0.0 & \\
1991 & 19 & 4 & 23 & 17.4 & \\
1992 & 40 & 5 & 45 & 11.1 & 1 \\
1993 & 54 & 13 & 67 & 19.4 & 3 \\
1994 & 60 & 5 & 65 & 7.7 & 4 \\
1995 & 52 & 2 & 54 & 3.7 & 3 \\
1996 & 29 & 4 & 33 & 12.1 & 2 \\
1998 & 35 & 14 & 49 & 28.6 & 2 \\
1999 & 18 & 9 & 27 & 33.3 & 3 \\
2000 & 10 & 4 & 14 & 28.6 & 5 \\
2001 & 9 & 3 & 12 & 25.0 & 4 \\
2002 & 6 & 4 & 10 & 40.0 & \\
2003 & 6 & 2 & 8 & 25.0 & 34 \\
2004 & 3 & 17 & 20 & 85.0 & \\
\hline Total & 34 & $\mathbf{8 6}$ & $\mathbf{4 3 0}$ & $\mathbf{2 0 . 0}$ & \\
\hline
\end{tabular}


Table 2

Summary statistics of MHC and non-MHCs prior to the IPO

ASSETS is calculated as the log of the firm's total assets in thousands in the year prior to the demutualization. PROC is defined as the log of proceeds from the offer in thousands. GROWTH is the percent increase in assets in the year prior to the conversion. ROA is the percent return on assets in the year prior to the offer. CORE is tier 1 capital divided by risk-adjusted assets as a percentage in the year prior to the offer. LOANS is loans divided by total assets as a percentage in the year prior to the offer. IND_P/B is the thrift industry average price-to-book ratio at the year of the demutualization. INSIDE is the percent of the shares purchased by officers and directors. $\triangle P R I C E$ is the percent price change at the IPO. Values are winsorized at the $5^{\text {th }}$ and $95^{\text {th }}$ percentile.

\begin{tabular}{|c|c|c|c|c|}
\hline Variable & $\begin{array}{c}\text { Non-MHC } \\
\text { firms } \\
(\mathrm{n}=344)\end{array}$ & $\begin{array}{l}\text { MHC firms } \\
(\mathrm{n}=86)\end{array}$ & $\begin{array}{l}\mathrm{t} \text {-value for } \\
\text { difference in } \\
\text { means }\end{array}$ & $\begin{array}{l}\text { p-value for } \\
\text { difference in } \\
\text { means }\end{array}$ \\
\hline $\begin{array}{l}\text { Total Assets from the Year } \\
\text { Prior to Conversion }\end{array}$ & $\$ 295,712,040$ & $\$ 376,629,000$ & -1.87 & .0627 \\
\hline ASSETS & 12.01 & 12.43 & -3.33 & .0009 \\
\hline Value of the Proceeds & $\$ 37,093,510$ & $\$ 26,941,370$ & 1.96 & .0502 \\
\hline PROC & 9.94 & 9.65 & 2.28 & .0231 \\
\hline GROWTH & $5.29 \%$ & $7.46 \%$ & -2.17 & .0304 \\
\hline$R O A$ & $0.68 \%$ & $0.77 \%$ & -1.73 & .0845 \\
\hline CORE & $18.61 \%$ & $19.05 \%$ & -0.49 & .6276 \\
\hline LOANS & $65.77 \%$ & $63.69 \%$ & 1.16 & .2475 \\
\hline$I N D \_P / B$ & $98.98 \%$ & $112.19 \%$ & -5.45 & .0001 \\
\hline INSIDE & $7.94 \%$ & $8.23 \%$ & -0.44 & .6608 \\
\hline$\triangle P R I C E$ & $20.97 \%$ & $20.94 \%$ & -0.01 & .9885 \\
\hline
\end{tabular}


Table 3

Logit estimates of choice of demutualization structure

The dependent variable is an indicator variable equal to 1 if the thrift chooses a mutual holding company structure and a 0 if the company chooses a full demutualization. ASSETS is calculated as the log of the firm's total assets in thousands in the year prior to the demutualization. GROWTH^ ${ }^{\wedge}$ is the percent increase in assets in the year prior to the conversion net of industry. $R O A^{\wedge}$ is the percent return on assets in the year prior to the offer net of industry. $C O R E^{\wedge}$ is tier 1 capital divided by risk-adjusted assets as a percentage in the year prior to the offer net of industry. $L O A N S \wedge$ is the loans-to-assets ratio in the year prior to the conversion net of industry. IND_P/B is the thrift industry average price-to-book ratio at the year of the demutualization. 1995-2000 is a dummy variable equal to 1 if the conversion occurs within the period February 1, 1995 to July 1, 2000. >2000 is a dummy variable equal to 1 if the conversion occurs after July 1, 2000. CONSTRAIN equals 1 if, in the year prior to conversion, the thrift exhibited low capital (CORE less than industry median), high profitability (ROA greater than the industry median), and high loans-to-assets (LOANS greater than the industry median). NON-CONSTRAIN equals 1 if, in the year prior to conversion, the thrift exhibited high capital (CORE greater than industry median), low profitability (ROA less than the industry median), and low loans-to-assets (LOANS less than the industry median). Values are winsorized at the $5^{\text {th }}$ and $95^{\text {th }}$ percentile. Similar conclusions are made when variables are not winsorized or when they are not adjusted for industry. The p-values are in parentheses. ${ }^{*},{ }^{* *}$, and ${ }^{* * *}$ denote significance at the .1, .05, and .01 levels respectively for two-tailed tests.

\begin{tabular}{ccc}
\hline Intercept & -9.838 & -10.381 \\
& $(.001)^{* * *}$ & $(.001)^{* * *}$ \\
ASSETS & 0.383 & 0.433 \\
& $(.005)^{* * *}$ & $(.002)^{* * *}$ \\
GROWTH^ & 0.006 & 0.009 \\
& $(.717)$ & $(.586)$ \\
ROA^ & .637 & 1.320 \\
& $(.089)^{*}$ & $(.003)^{* * *}$ \\
CORE^ & 0.017 & -0.013 \\
& $(.458)$ & $(.604)$ \\
LOANS^ & -0.012 & 0.002 \\
& $(.217)$ & $(.889)$ \\
IND_P/B & 0.040 & 0.041 \\
& $(.001)^{* * *}$ & $(.001)^{* * *}$ \\
1995-2000 & -1.010 & -1.050 \\
& $(.012)^{* *}$ & $(.010)^{* * *}$ \\
>2000 & 0.680 & 0.683 \\
& $(.126)$ & $(.136)$ \\
CONSTRAIN & & -1.742 \\
Dikelihood Ratio & & $(.009)^{* * *}$ \\
P-Value & .0001 & 0.865 \\
NON-CONSTRAIN & & $(.041)^{* *}$ \\
& & 430 \\
& & 83.34 \\
& & .0001 \\
\hline
\end{tabular}




\section{Table 4}

Summary statistics (mean values) of selected variables after the IPO

Percent changes are measured as the firm ratio 3 years following the IPO divided by the firm ratio from the year prior to the IPO less the industry ratio 3-years following the IPO divided by industry ratio the year prior to the IPO. The sample is limited to firms with data following the IPO. The number of firms with complete data for analysis is indicated in parentheses.

\begin{tabular}{|c|c|c|c|}
\hline Variable & $\begin{array}{l}\text { Non-MHC } \\
\text { firms }\end{array}$ & MHC firms & $\begin{array}{l}\text { p-value for } \\
\text { difference } \\
\text { in means }\end{array}$ \\
\hline $\begin{array}{c}\text { Assets } \\
\text { (3 years after IPO) }\end{array}$ & $\begin{array}{l}\$ 664,961,000 \\
(241)\end{array}$ & $\begin{array}{l}\$ 998,865,000 \\
(55)\end{array}$ & 0.152 \\
\hline $\begin{array}{l}\text { \% Change in Assets Net of Industry } \\
\text { (1 year before to } 3 \text { years after IPO) }\end{array}$ & $\begin{array}{c}61.66 \% \\
(241)\end{array}$ & $\begin{array}{l}42.09 \% \\
(55)\end{array}$ & 0.042 \\
\hline $\begin{array}{c}\text { Tier1 Capital } \\
\text { (3 years after IPO) }\end{array}$ & $\begin{array}{c}19.98 \% \\
(241)\end{array}$ & $\begin{array}{l}22.31 \% \\
(55)\end{array}$ & 0.097 \\
\hline $\begin{array}{c}\text { \% Change in Tier } 1 \text { Capital Net of Industry } \\
\text { (1 year before to } 3 \text { years after IPO) }\end{array}$ & $\begin{array}{l}7.10 \% \\
(241)\end{array}$ & $\begin{array}{l}18.56 \% \\
(55)\end{array}$ & 0.051 \\
\hline $\begin{array}{c}\text { ROA } \\
\text { (3 years after IPO) }\end{array}$ & $\begin{array}{c}0.79 \% \\
(241)\end{array}$ & $\begin{array}{l}0.87 \% \\
(55)\end{array}$ & 0.175 \\
\hline $\begin{array}{l}\% \text { Change in ROA Net of Industry } \\
\text { ( } 1 \text { year before to } 3 \text { years after IPO) }\end{array}$ & $\begin{array}{c}19.44 \% \\
(220)\end{array}$ & $\begin{array}{l}18.23 \% \\
(53)\end{array}$ & 0.934 \\
\hline $\begin{array}{l}\text { Loans-to-Assets } \\
\text { (3 years after IPO) }\end{array}$ & $\begin{array}{c}67.64 \% \\
(241)\end{array}$ & $\begin{array}{l}63.07 \% \\
(55)\end{array}$ & 0.034 \\
\hline $\begin{array}{l}\text { \% Change in Loans-to-Assets Net of Industry } \\
\text { (1 year before to } 3 \text { years after IPO) }\end{array}$ & $\begin{array}{c}5.41 \% \\
(240)\end{array}$ & $\begin{array}{l}-2.80 \% \\
(55)\end{array}$ & 0.089 \\
\hline $\begin{array}{c}\text { NIM } \\
\text { (3 years after IPO) }\end{array}$ & $\begin{array}{c}3.37 \% \\
(241)\end{array}$ & $\begin{array}{l}3.46 \% \\
(55)\end{array}$ & 0.323 \\
\hline $\begin{array}{l}\% \text { Change in NIM Net of Industry } \\
\text { ( } 1 \text { year before to } 3 \text { years after IPO) }\end{array}$ & $\begin{array}{c}0.83 \% \\
(240)\end{array}$ & $\begin{array}{c}-0.20 \% \\
(55)\end{array}$ & 0.699 \\
\hline $\begin{array}{l}\text { Nonperforming Assets to Assets } \\
\text { (3 years after IPO) }\end{array}$ & $\begin{array}{l}55.55 \% \\
(240)\end{array}$ & $\begin{array}{l}34.93 \% \\
(55)\end{array}$ & 0.031 \\
\hline $\begin{array}{c}\% \text { Change in Nonperforming Assets to Assets Net of Industry } \\
\text { ( } 1 \text { year before to } 3 \text { years after IPO) }\end{array}$ & $\begin{array}{c}-0.00 \% \\
(239)\end{array}$ & $\begin{array}{l}0.00 \% \\
(55)\end{array}$ & 0.510 \\
\hline $\begin{array}{l}\text { Reserves to Loans } \\
\text { (3 years after IPO) }\end{array}$ & $\begin{array}{l}0.79 \% \\
(241)\end{array}$ & $\begin{array}{c}0.78 \% \\
(55)\end{array}$ & 0.823 \\
\hline $\begin{array}{l}\text { \% Change in Reserves to Loans Net of Industry } \\
\text { (1 year before to } 3 \text { years after IPO) }\end{array}$ & $\begin{array}{l}15.26 \% \\
(238)\end{array}$ & $\begin{array}{l}-5.50 \% \\
(55)\end{array}$ & 0.016 \\
\hline
\end{tabular}




\section{Table 5}

\section{Regressions explaining offer-day returns}

The dependent variables are the one-day percent price change and the total one-day dollar gain at the time of the IPO. ASSETS is calculated as the log of the firm's total assets in thousands in the year prior to the demutualization. GROWTH^ is the percent increase in assets in the year prior to the conversion net of industry. $R O A^{\wedge}$ is the percent return on assets in the year prior to the offer net of industry. $C O R E^{\wedge}$ is tier 1 capital divided by risk-adjusted assets as a percentage in the year prior to the offer net of industry. $L O A N S^{\wedge}$ is the loans-to-assets ratio in the year prior to the conversion net of industry. IND_P/B is the thrift industry average price-to-book ratio at the year of the demutualization. $E X C H$ is equal to one if traded on the NYSE, AMEX, or NASDAQ - zero otherwise. INSIDE is the percent of the shares purchased by officers and directors. INDEX is the return on the thrift index in the six-week period preceding the offer. CMT is the six-week change in the ten-year Constant Maturity Treasury yield. $M H C<1995, M H C=1995-2000$, and $M H C>2000$ are dummy variables equal to 1 if the thrift used an MHC structure to demutualize within the specified period. MHC_CONSTRAIN, NONMHC_CONSTRAIN, MHC_NON-CONSTRAIN, and NONMHC_NON-CONSTRAIN are a series of interaction variables considering both the MHC choice and the degree of capital constraints as defined in Table 3 . Values are winsorized at the $5^{\text {th }}$ and $95^{\text {th }}$ percentile. Similar conclusions are made when variables are not winsorized or when they are not adjusted for industry. The t-values are in parentheses. ${ }^{*},{ }^{* *}$, and ${ }^{* * *}$ denote significance at the $.1, .05$, and .01 levels respectively for two-tailed tests.

\begin{tabular}{|c|c|c|c|c|}
\hline & \multicolumn{4}{|c|}{ Dependent Variable } \\
\hline Independent & IPO & IPO & IPO & IPO \\
\hline Variables & \% Price Change & \% Price Change & Total \$ Gain & Total \$ Gain \\
\hline Intercept & $\begin{array}{c}-80.09 \\
(-6.65)^{* * *}\end{array}$ & $\begin{array}{c}-80.25 \\
(6.68)^{* * * *}\end{array}$ & $\begin{array}{c}-5.49 \\
(-1.70)^{*}\end{array}$ & $\begin{array}{c}-5.37 \\
(-1.66)^{*}\end{array}$ \\
\hline ASSETS & $\begin{array}{c}5.26 \\
(5.86)^{* * *}\end{array}$ & $\begin{array}{c}5.22 \\
(5.82)^{* * *}\end{array}$ & $\begin{array}{c}1.02 \\
(4.24)^{* * * *}\end{array}$ & $\begin{array}{c}1.00 \\
(4.15)^{* * *}\end{array}$ \\
\hline GROWTH^ & $\begin{array}{c}0.08 \\
(1.04)\end{array}$ & $\begin{array}{c}0.08 \\
(0.93)\end{array}$ & $\begin{array}{c}-0.01 \\
(-0.30)\end{array}$ & $\begin{array}{c}-0.01 \\
(-0.39)\end{array}$ \\
\hline$R O A^{\wedge}$ & $\begin{array}{c}5.47 \\
(3.06)^{* * *}\end{array}$ & $\begin{array}{c}5.44 \\
(2.66)^{* * *}\end{array}$ & $\begin{array}{c}1.41 \\
(2.95)^{* * * *}\end{array}$ & $\begin{array}{c}1.37 \\
(2.49)^{* *}\end{array}$ \\
\hline$C O R E^{\wedge}$ & $\begin{array}{c}0.28 \\
(2.56)^{* *}\end{array}$ & $\begin{array}{c}0.29 \\
(2.38)^{* *}\end{array}$ & $\begin{array}{c}0.06 \\
(2.11)^{* *}\end{array}$ & $\begin{array}{c}0.07 \\
(2.00)^{* *}\end{array}$ \\
\hline LOANS^ & $\begin{array}{c}0.06 \\
(1.31)\end{array}$ & $\begin{array}{c}0.05 \\
(1.04)\end{array}$ & $\begin{array}{c}0.02 \\
(1.30)\end{array}$ & $\begin{array}{c}0.01 \\
(0.98)\end{array}$ \\
\hline$I N D \_P / B$ & $\begin{array}{c}0.25 \\
(6.86)^{* * *}\end{array}$ & $\begin{array}{c}0.26 \\
(7.13)^{* * *}\end{array}$ & $\begin{array}{c}0.02 \\
(2.45)^{* *}\end{array}$ & $\begin{array}{c}0.03 \\
(2.63)^{* * * *}\end{array}$ \\
\hline $\mathrm{EXCH}$ & $\begin{array}{c}0.16 \\
(0.08)\end{array}$ & $\begin{array}{c}0.54 \\
(0.27)\end{array}$ & $\begin{array}{c}0.90 \\
(1.70)^{*}\end{array}$ & $\begin{array}{c}0.98 \\
(1.86)^{*}\end{array}$ \\
\hline INSIDE & $\begin{array}{c}0.50 \\
(3.50)^{* * *}\end{array}$ & $\begin{array}{c}0.50 \\
(3.53)^{* * *}\end{array}$ & $\begin{array}{c}0.04 \\
(1.13)\end{array}$ & $\begin{array}{c}0.04 \\
(1.12)\end{array}$ \\
\hline INDEX & $\begin{array}{c}2.41 \\
(10.88)^{* * * *}\end{array}$ & $\begin{array}{c}2.41 \\
(10.89)^{* * * *}\end{array}$ & $\begin{array}{c}0.40 \\
(6.70)^{* * *}\end{array}$ & $\begin{array}{c}0.40 \\
(6.65)^{* * *}\end{array}$ \\
\hline$C M T$ & $\begin{array}{c}-1.67 \\
(-0.78)\end{array}$ & $\begin{array}{l}-1.43 \\
(-0.67)\end{array}$ & $\begin{array}{c}-0.78 \\
(-1.36)\end{array}$ & $\begin{array}{c}-0.74 \\
(-1.30)\end{array}$ \\
\hline$M H C<1995$ & $\begin{array}{c}1.21 \\
(0.40)\end{array}$ & $\begin{array}{c}2.48 \\
(0.80)\end{array}$ & $\begin{array}{c}-1.94 \\
(-2.43)^{* *}\end{array}$ & $\begin{array}{l}-1.76 \\
(-2.10)^{* *}\end{array}$ \\
\hline$M H C=1995-2000$ & $\begin{array}{c}-6.97 \\
(-2.72)^{* * *}\end{array}$ & $\begin{array}{c}-7.68 \\
(-2.84)^{* * *}\end{array}$ & $\begin{array}{c}-2.72 \\
(-3.95)^{* * *}\end{array}$ & $\begin{array}{c}-2.91 \\
(-3.99)^{* * *}\end{array}$ \\
\hline$M H C>2000$ & $\begin{array}{l}-4.65 \\
(-1.60)\end{array}$ & $\begin{array}{c}-3.82 \\
(-1.18)\end{array}$ & $\begin{array}{c}0.56 \\
(0.71)\end{array}$ & $\begin{array}{c}0.65 \\
(0.74)\end{array}$ \\
\hline MHC_CONSTRAIN & & $\begin{array}{c}-19.92 \\
(-2.80)^{* * *}\end{array}$ & & $\begin{array}{c}-3.57 \\
(-1.86)^{*}\end{array}$ \\
\hline NONMHC_CONSTRAIN & & $\begin{array}{l}-0.87 \\
(-0.32)\end{array}$ & & $\begin{array}{l}-0.30 \\
(-0.42)\end{array}$ \\
\hline MHC_NON-CONSTRAIN & & $\begin{array}{c}-0.04 \\
(-0.01)\end{array}$ & & $\begin{array}{c}-0.02 \\
(-0.02)\end{array}$ \\
\hline NONMHC_NON-CONSTRAIN & & $\begin{array}{c}-2.97 \\
(-1.25)\end{array}$ & & $\begin{array}{c}-0.81 \\
(-1.26)\end{array}$ \\
\hline Observations & 430 & 430 & 430 & 430 \\
\hline Adjusted $\mathrm{R}^{2}$ & .333 & .343 & .226 & .229 \\
\hline$p$-value of $F$-test & .0001 & .0001 & .0001 & .0001 \\
\hline
\end{tabular}


Table 6

Summary statistics on mergers and acquisitions after the IPO

\begin{tabular}{lcccc}
\hline \multicolumn{1}{c}{ Variable } & $\begin{array}{c}\text { Non- } \\
\text { MHC } \\
\text { firms } \\
(\mathrm{n}=344)\end{array}$ & $\begin{array}{c}\text { MHC } \\
\text { firms } \\
(\mathrm{n}=86)\end{array}$ & $\begin{array}{c}\text { t-value } \\
\text { for } \\
\text { difference } \\
\text { in means }\end{array}$ & $\begin{array}{c}\text { p-value } \\
\text { for } \\
\text { difference } \\
\text { in means }\end{array}$ \\
\hline Percent of firms that were subsequently acquired & 39.2 & 9.3 & 5.44 & 0.001 \\
Number of years from initial offer to becoming a target & 3.93 & 3.88 & 0.08 & 0.935 \\
Percent of firms that subsequently made an acquisition & 23.0 & 18.6 & 0.87 & 0.382 \\
Number of years from initial offer to the acquisition & 3.25 & 6.94 & -5.38 & 0.001 \\
\hline
\end{tabular}




\section{Table 7}

Summary statistics of stock performance after the IPO

Cumulative stock returns and cumulative stock returns net of thrift industry exclude the return on the offer date. The industry returns are based on a sample of the thrift stocks available on CRSP during the sample period. Sample size decreases due to acquisition and delisting.

\begin{tabular}{|c|c|c|c|c|}
\hline Variable & $\begin{array}{l}\text { Non- } \\
\text { MHC } \\
\text { firms }\end{array}$ & $\begin{array}{l}\text { MHC } \\
\text { firms }\end{array}$ & $\begin{array}{c}\text { t-value } \\
\text { for } \\
\text { difference } \\
\text { in means }\end{array}$ & $\begin{array}{c}\mathrm{p} \text {-value } \\
\text { for } \\
\text { difference } \\
\text { in means }\end{array}$ \\
\hline \multicolumn{5}{|l|}{ Cumulative Stock Returns } \\
\hline $\begin{array}{l}\text { One year after IPO } \\
\text { (sample size) }\end{array}$ & $\begin{array}{c}31.71 \% \\
(271)\end{array}$ & $\begin{array}{l}20.58 \% \\
(48)\end{array}$ & 2.15 & 0.032 \\
\hline $\begin{array}{l}\text { Two years after IPO } \\
\text { (sample size) }\end{array}$ & $\begin{array}{l}55.82 \% \\
(260)\end{array}$ & $\begin{array}{l}53.09 \% \\
(48)\end{array}$ & 0.30 & 0.764 \\
\hline $\begin{array}{l}\text { Three years after IPO } \\
\text { (sample size) }\end{array}$ & $\begin{array}{l}87.88 \% \\
(236)\end{array}$ & $\begin{array}{l}123.68 \% \\
(47)\end{array}$ & -2.38 & 0.018 \\
\hline \multicolumn{5}{|c|}{ Cumulative Stock Returns Net of Thrift Industry } \\
\hline $\begin{array}{l}\text { One year after IPO } \\
\text { (sample size) }\end{array}$ & $\begin{array}{c}-7.90 \% \\
(271)\end{array}$ & $\begin{array}{c}-9.98 \% \\
(48)\end{array}$ & 0.53 & 0.600 \\
\hline $\begin{array}{l}\text { Two years after IPO } \\
\text { (sample size) }\end{array}$ & $\begin{array}{c}-35.30 \% \\
(260)\end{array}$ & $\begin{array}{c}-20.21 \% \\
(48)\end{array}$ & -2.11 & 0.037 \\
\hline $\begin{array}{l}\text { Three years after IPO } \\
\text { (sample size) }\end{array}$ & $\begin{array}{c}-58.20 \% \\
(236)\end{array}$ & $\begin{array}{c}-19.11 \% \\
(47)\end{array}$ & -3.29 & 0.001 \\
\hline
\end{tabular}




\section{Table 8}

Abnormal returns relating to second-stage offers

Abnormal returns are estimated using the market model over a period beginning 120 days prior to the event and ending the day prior to the event. The market is proxied by the CRSP value-weighted index.

\begin{tabular}{|c|c|c|c|}
\hline & Number of Firms & CAR & t-value \\
\hline Two-day CAR $(0,1)$ & 30 & $12.27 \%$ & $27.07 * * *$ \\
\hline One-day CAR(0) & 30 & $7.86 \%$ & $22.88 * * *$ \\
\hline \multicolumn{4}{|c|}{ Part B: Abnormal Returns at the offer date for subscribers - measured from the offer price } \\
\hline & Number of Firms & CAR & t-value \\
\hline Two-day CAR(0,1) & 30 & $10.12 \%$ & $21.16 * * *$ \\
\hline One-day CAR(0) & 30 & $9.48 \%$ & $28.20 * * *$ \\
\hline \multicolumn{4}{|c|}{ Part C: Abnormal Returns at the offer date for non-subscribers - measured from the previous day's closing price } \\
\hline & Number of Firms & CAR & t-value \\
\hline Two-day CAR(0,1) & 30 & $-1.11 \%$ & -1.34 \\
\hline One-day CAR(0) & 30 & $-1.70 \%$ & $-3.28 * * *$ \\
\hline
\end{tabular}

